\title{
Phase state of ambient aerosol linked with water uptake and chemical aging in the southeastern US
}

\author{
Aki Pajunoja ${ }^{1}$, Weiwei Hu ${ }^{2,3}$, Yu J. Leong ${ }^{1,4}$, Nathan F. Taylor ${ }^{5}$, Pasi Miettinen ${ }^{1}$, Brett B. Palm ${ }^{2,3}$, Santtu Mikkonen ${ }^{1}$, \\ Don R. Collins ${ }^{5}$, Jose L. Jimenez ${ }^{2,3}$, and Annele Virtanen ${ }^{1}$ \\ ${ }^{1}$ Department of Applied Physics, University of Eastern Finland, Kuopio Campus, P.O. Box 1627, 70211 Kuopio, Finland \\ ${ }^{2}$ Cooperative Institute for Research in Environmental Sciences, University of Colorado, Boulder, CO, USA \\ ${ }^{3}$ Department of Chemistry and Biochemistry, University of Colorado, Boulder, CO, USA \\ ${ }^{4}$ Department of Civil and Environmental Engineering, Rice University, 6100 Main St MS-519, Houston, TX, USA \\ ${ }^{5}$ Department of Atmospheric Sciences, Texas A\&M University, College Station, TX, USA
}

Correspondence to: Annele Virtanen (annele.virtanen@uef.fi)

Received: 3 May 2016 - Published in Atmos. Chem. Phys. Discuss.: 9 May 2016

Revised: 26 August 2016 - Accepted: 30 August 2016 - Published: 9 September 2016

\begin{abstract}
During the summer 2013 Southern Aerosol and Oxidant Study (SOAS) field campaign in a rural site in the southeastern United States, the effect of hygroscopicity and composition on the phase state of atmospheric aerosol particles dominated by the organic fraction was studied. The analysis is based on hygroscopicity measurements by a Hygroscopic Tandem Differential Mobility Analyzer (HTDMA), physical phase state investigations by an Aerosol Bounce Instrument (ABI) and composition measurements using a highresolution time-of-flight aerosol mass spectrometer (HRToF-AMS). To study the effect of atmospheric aging on these properties, an $\mathrm{OH}$-radical oxidation flow reactor (OFR) was used to simulate longer atmospheric aging times of up to 3 weeks. Hygroscopicity and bounce behavior of the particles had a clear relationship showing higher bounce at elevated relative humidity (RH) values for less hygroscopic particles, which agrees well with earlier laboratory studies. Additional $\mathrm{OH}$ oxidation of the aerosol particles in the OFR increased the $\mathrm{O}: \mathrm{C}$ and the hygroscopicity resulting in liquefying of the particles at lower RH values. At the highest $\mathrm{OH}$ exposures, the inorganic fraction starts to dominate the bounce process due to production of inorganics and concurrent loss of organics in the OFR. Our results indicate that at typical ambient RH and temperature, organic-dominated particles stay mostly liquid in the atmospheric conditions in the southeastern US, but they often turn semisolid when dried below $\sim 50 \% \mathrm{RH}$ in the sampling inlets. While the liquid phase state suggests solution behavior and equilibrium par-
\end{abstract}

titioning for the SOA particles in ambient air, the possible phase change in the drying process highlights the importance of thoroughly considered sampling techniques of SOA particles.

\section{Introduction}

Atmospheric secondary organic aerosols (SOAs) result from gas-phase oxidation of volatile organic compounds (VOCs) (Hallquist et al., 2009), which are emitted from anthropogenic and biogenic sources. Chemical aging of the SOA particles in the atmosphere controls their physical and chemical properties such as phase state (Pajunoja et al., 2015), volatility (Kroll et al., 2011) and hygroscopicity (Jimenez et al., 2009; Massoli et al., 2010). Phase state and water uptake properties can also affect the growth of the SOA particles (Riipinen et al., 2012; Shiraiwa and Seinfeld, 2012). All these factors can affect the particles' ability to act as cloud condensation nuclei $(\mathrm{CCN})$ and ice nuclei (aerosolcloud interaction, ACI) or to scatter and absorb solar radiation (aerosol-radiation interaction, ARI) (Stocker et al., 2014).

Several recent studies have shown that SOA particles can be in a semisolid physical phase depending on the particle composition and surrounding humidity conditions (Virtanen et al., 2011; Renbaum-Wolff et al., 2013; Pajunoja et al., 2014; Bateman et al., 2014; Pajunoja et al., 2015; Song 
et al., 2015; Zhang et al., 2015). The phase state is typically represented by the viscosity of the material: materials with viscosities less than $10^{2} \mathrm{~Pa}$ s are considered liquids, with $10^{2}-10^{12} \mathrm{~Pa}$ as semisolids and viscosities greater than $10^{12} \mathrm{~Pa}$ s represent amorphous solid, glassy, material (Koop et al., 2011; Shiraiwa et al., 2011). Material viscosity depends on temperature and relative humidity as particle-phase water can act as a plasticizer (Zobrist et al., 2011) and can decrease the glass transition temperature of the material (Wang et al., 2014). The semisolid or solid phase state of the SOA particles can limit the diffusion of condensable gas-phase molecules from the surface into the particle bulk (Koop et al., 2011; Shiraiwa et al., 2011; Riipinen et al., 2012; Kuwata and Martin, 2012; Lienhard et al., 2014). This may affect inner mixing and disturb the equilibrium in gas-particle partitioning and result in slower evaporation of the particles than expected (Vaden et al., 2011; Saleh et al., 2011; Perraud et al., 2012; Abramson et al., 2013). Zaveri et al. (2014) took the lower diffusion rates into account in modeling kinetic partitioning and particle size distribution kinetics. Recently, the kinetic approach, where organic material condenses according to the surface area rather than the organic mass of particles, has been tested in the aerosol microphysics models (Shrivastava et al., 2013; Scott et al., 2015). The existence of very low volatility compounds in the particles may also considerably decrease the particle evaporation rates (Cappa and Wilson, 2011; Ehn et al., 2014). Transport of small molecules into the particle bulk (e.g., $\mathrm{H}_{2} \mathrm{O}, \mathrm{O}_{3}$ ) may not be limited by diffusion in the organic matrix within atmospherically relevant timescales and at temperatures close to room temperature (Price et al., 2014; Pajunoja et al., 2015). However, it has been recently shown that at low temperatures kinetic limitations of water diffusion in organic aerosol particle can affect the ice nucleation processes (Wang et al., 2012; Berkemeier et al., 2014). It should be noted that despite the recent SOA viscosity studies, most of the current regional and global aerosol models treat particles as liquid droplets considering no particle phase diffusion limitations.

Several studies have focused on the relationship between the aerosol hygroscopicity (quantified with the hygroscopicity parameter $\kappa$ ) and degree of oxidation (measured as $\mathrm{O}: \mathrm{C}$ ) showing the correlation between these two factors (e.g., Jimenez et al., 2009; Massoli et al., 2010; Duplissy et al., 2011) while some studies did not show a clear correlation between these parameters (Meyer et al., 2009; Tritscher et al., 2011; Alfarra et al., 2013). There is a lack of studies relating these two factors to physical phase state of the particles. Recent laboratory studies (Pajunoja et al., 2015) showed that the decrease in the liquefying relative humidity (RH) with $\mathrm{O}: \mathrm{C}$ can be related to the increasing hygroscopicity $\kappa$ measured under subsaturated conditions. They also showed that for laboratory-generated semisolid SOA particles, the low water solubility, rather than particle-phase diffusion, restricts the water uptake of SOA. Similar conclusions were drawn by $\mathrm{Li}$ et al. (2015). In addition, there are only very few studies on physical phase state of atmospheric aerosols. Virtanen et al. (2010) reported that aerosol particles in boreal forests dominated by SOA can be amorphous solids under dry conditions. More recently, Bateman et al. (2016) showed that in the Amazonian rain forest the particles are always liquid at relative humidity conditions relevant for that area. Apart from these studies, the information on the physical phase of the atmospheric organic aerosols is scarce and the data showing the relationship of particle physical phase to the $\mathrm{O}: \mathrm{C}$ and $\kappa$ for ambient aerosol dominated by the organic fraction are lacking.

This study focuses on characterizing the phase state of ambient aerosol particles and on how hygroscopicity and composition of atmospheric particles dominated by organic compounds affects the phase state of the particles. Direct viscosity or diffusion coefficient measurements are very challenging for ambient conditions where concentrations are low and conditions can be changing relatively rapidly. Instead, we use a robust method based on detection of particle bounce during impaction to infer information about the physical phase of the ambient aerosol particles (Virtanen et al., 2010; Saukko et al., 2012; Bateman et al., 2014; Pajunoja et al., 2015; Bateman et al., 2016). The measurements were performed in a rural environment in the southern US during the Southern Aerosol and Oxidant Study (SOAS) (http://soas2013.rutgers.edu) field campaign in the summer of 2013. In this study, we utilize the data from the aerosol bounce instrument (ABI), a hygroscopic tandem differential mobility analyzer (HTDMA) and a high-resolution time-offlight aerosol mass spectrometer (HR-ToF-AMS) to study the relation of aerosol physical state to aerosol composition, $\mathrm{O}: \mathrm{C}$ of the organic fraction and particle hygroscopicity.

\section{Experimental methods}

The measurements were conducted in a rural site in Centreville, Alabama, between 1 June and 15 July 2013 during the SOAS campaign. The southeastern US represents an unusual region with a cooling trend compared to the long-term warming trend observed in other parts of the US (Goldstein et al., 2009). The measurement site represents an isoprene- and terpene-rich environment (Guenther et al., 2012) with anthropogenic influence, where the isoprene and terpene SOA and more oxidized organic aerosols are the main organic aerosol (OA) constituents (Budisulistiorini et al., 2015; Cerully et al., 2015; Hu et al., 2015; Lee et al., 2016) and the main contributors for the hygroscopicity of the organic fraction (Cerully et al., 2015). The data from ABI, HTDMA and AMS were utilized in the study and the sampling and measurement conditions for each system are described in detail below. 


\subsection{ABI measurements and inferred phase state}

ABI was developed to indicate the phase state of SOA particles by measuring the bounced fraction $(\mathrm{BF})$ of the particles (Pajunoja et al., 2015; Saukko et al., 2012; Virtanen et al., 2011). In this study, the same setup of ABI was employed as in Pajunoja et al. (2015). The ABI was housed in an air-conditioned container sampling through a $3 \mathrm{~m}$ long (above the container) stainless steel tube with residence time of the sample in the inlet being approximately $5 \mathrm{~s}$. In the ABI, the particles are dried in a silica gel diffusion dryer to 25$30 \% \mathrm{RH}$, neutralized with a radioactive ${ }^{210}$ Po strip and then size selected with a differential mobility analyzer (DMA, custom-made, open loop sheath flow system). Dried and filtered compressed air was used as sheath air in the DMA with sample-to-sheath flow ratio of $1: 5$ (i.e., 2 and $10 \mathrm{~L} \mathrm{~min}^{-1}$ ). The monodisperse aerosol flow passes through a needle valve for the humidification control unit. The control unit consists of two Nafion humidifiers. The first one (Permapure Inc., model PD-24-SS) is used for humidifying the sheath air of the second Nafion humidifier (Permapure Inc., model PD240-12SS) which is used for humidifying the sample air. The humidity was varied between $\sim 30$ and $70 \%$ in the humidity control unit but the scanning was performed slowly with always less than $10 \%$ RH per hour change. To optimize the time resolution of the measurement, the $\mathrm{RH}$ range of $\sim 30$ $70 \%$ was chosen based on the previous laboratory measurements that showed the biggest changes in bounce for isoprene and highly oxidized monoterpene SOA occurred in that RH range (Pajunoja et al., 2015). Residence time of the aerosol in the humidified region is approximately $8 \mathrm{~s}$, which is a long enough time for particles to reach equilibrium with surrounding water vapor based on study by Shiraiwa et al. (2013). Shiraiwa et al. (2013) estimated that the hygroscopic growth times of particles in the size range of our study is in the order of milliseconds. The initial humidified monodisperse particle number concentration is measured with a CPC (TSI, 3010) prior to the MOUDI single-stage impactor. The impactor plate is covered with polished and cleaned aluminum foil. The number concentration in the output flow of the impactor is measured by another CPC (TSI, 3010) and the BF is calculated based on the ratio of these two CPC readings. The calculations are described elsewhere in more detail $(\mathrm{Pa}-$ junoja et al., 2015). The upstream pressure was adjusted to $850 \pm 10$ mbar while the downstream pressure was kept at $700 \pm 10$ mbar. This pressure difference leads to a cut-off size of the impactor stage of $67 \mathrm{~nm}$ in aerodynamic size. The impactor stage was calibrated with dioctyl sebacate (DOS, Sigma-Aldrich) oil particles prior to and after the campaign. In this study, $100 \mathrm{~nm}$ particles (electrical mobility diameter) were selected to make sure that the aerodynamic sizes are clearly higher than the cut-off of the impactor stage. RH sensors (Vaisala, HMP-110) in the ABI were tested with bounce behavior of pure ammonium sulfate particles before and after the campaign and the offset between the two CPCs (i.e.,
$\left.\mathrm{BF}_{\text {reference, }} \Delta \mathrm{BF}_{\text {reference }}= \pm 0.02\right)$ was measured every second day.

The phase state of the submicron OA particles is inferred based on the ABI measurements. Based on laboratory measurements, the particles can be classified as semisolid and liquid particles based on their bounce behavior; the particles having $\mathrm{BF}>0.8$ are semisolid or solid (nonliquid) and for the particles having $\mathrm{BF}<0.1$ the phase transition to liquid has been completed. When $\mathrm{BF}$ is between 0.1 and 0.8 the particles are in the range of phase transition. A similar classification was introduced and used previously (Saukko et al., 2012; Bateman et al., 2014; Pajunoja et al., 2015) but a simple relationship between BF and viscosity has not been published. Pajunoja et al. (2015) and Li et al. (2015) also used the transition RH from nonliquid to liquid (i.e., RH where BF reaches $\sim 0$, liquefying $\mathrm{RH}$ ) as a parameter representing phase state of the SOA particles. The classification requires particles to be composed of an amorphous phase material. To focus especially on the properties of organic fraction of the particles, only the data points where the mass fraction of OA is $f_{\mathrm{OA}} \geq 0.6$ have been taken into account in the analyses below. However, as aerosol particles are oxidized further by an OH-OFR, $f_{\mathrm{OA}}$ can decrease remarkably and thus inorganics may start to control the bounce behavior (see Sect. 3.2.).

\subsection{HR-ToF-AMS measurements and chemical composition}

Nonrefractory submicron particle-phase masses were measured by an Aerodyne High Resolution Time-of-Flight Aerosol Mass Spectrometer (HR-ToF-AMS, hereafter called AMS) to quantify OA, sulfate, nitrate, ammonium and chloride (DeCarlo et al., 2006). The elemental compositions (oxygen to carbon ratio, $\mathrm{O}: \mathrm{C}$ and hydrogen to carbon ratio, $\mathrm{H}: \mathrm{C}$ ) of total OA were quantified from the high-resolution spectra using the updated ambient calibrations of Canagaratna et al. (2015). Detailed information on AMS analysis and measurements can be found in $\mathrm{Hu}$ et al. (2015).

Organic and inorganic fractions of particles were calculated based on AMS analysis (Canagaratna et al., 2007). The composition of $\mathrm{PM}_{1}$ was assumed to represent the average composition of the particle sizes selected in ABI and HTDMA for the analysis. The measured aerosol material can be divided into inorganic ions $\left(\left[\mathrm{NH}_{4}^{+}\right],\left[\mathrm{SO}_{4}^{2-}\right],\left[\mathrm{Cl}^{-}\right]\right.$, $\left.\left[\mathrm{NO}_{3}^{-}\right]\right)$and organic ([OA]) mass concentrations. Actual inorganic salts present in the particle phase are then estimated based on the method introduced by Nenes et al. (1998). In the analysis, the inorganic aerosol is divided into three categories based on a molar ratio of ammonium ions to sulfate ions, $R_{\mathrm{SO}_{4}}=\left[\mathrm{NH}_{4}^{+}\right] /\left[\mathrm{SO}_{4}^{2-}\right]$ according to the following classifications: (1) if $R_{\mathrm{SO}_{4}}<1$, sulfate exists as a mixture of sulfuric acid (SA) and ammonium bisulfate (ABS); (2) if $1<R_{\mathrm{SO}_{4}}<2$, sulfate is in form of ammonium sulfate (AS) and ABS; and (3) if $R_{\mathrm{SO}_{4}}>2$, sulfate is existing as AS (Nenes et al., 1998; Cerully et al., 2015). The classification assumes 
Table 1. Literature values of density, molar mass, deliquescence point (DRH), efflorescence point (ERH) and hygroscopicity $\kappa$ for inorganic species. Hygroscopicities of inorganics listed here are based on the E-AIM model (Clegg et al., 1998). Variables written in italic style are campaign medians with quartiles in the brackets.

\begin{tabular}{lrrrr}
\hline & \multicolumn{4}{c}{ Categorized $^{\mathrm{a}}$ components of $\mathrm{PM}_{1}$} \\
\hline Abbreviation & $\mathrm{AS}$ & $\mathrm{ABS}$ & $\mathrm{SA}$ & $\mathrm{OA}$ \\
Molec. formula & $\left(\mathrm{NH}_{4}\right)_{2} \mathrm{SO}_{4}$ & $\mathrm{NH}_{4} \mathrm{HSO}_{4}$ & $\mathrm{H}_{2} \mathrm{SO}_{4}$ & - \\
Density $\left(\mathrm{kg} \mathrm{m}^{-3}\right)$ & 1770 & 1780 & 1840 & 1400 \\
Molar mass $\left(\mathrm{g} \mathrm{mol}^{-1}\right)$ & 132.14 & 115.11 & 98.08 & $210(124 / 390)$ \\
$\kappa_{\mathrm{HGF}}$ at $90 \% \mathrm{RH}$ & $0.45^{\mathrm{d}}$ & $0.68^{\mathrm{d}}$ & $1.18^{\mathrm{e}}$ & $0.10(0.04 / 0.16)$ \\
DRH $(\mathrm{RH} \%)$ & $80^{\mathrm{b}}$ & $40^{\mathrm{c}}$ & - & - \\
ERH $(\mathrm{RH} \%)$ & $28^{\mathrm{b}}-36^{\mathrm{c}}$ & $<22^{\mathrm{c}}$ & - & - \\
Volume fraction & $0(0 / 1)$ & $21(15 / 27)$ & $3(1 / 9)$ & $73(66 / 79)$ \\
\hline
\end{tabular}

${ }^{a}$ Nenes et al. (1998). ${ }^{b}$ Smith et al. (2012). ${ }^{c}$ Tang and Munkelwitz (1994). ${ }^{d}$ E-AIM. ${ }^{e}$ Residual water ignored.

the contribution of nitrates $\left(<1 \%\right.$ of total $\mathrm{PM}_{1}$ in SOAS) and other inorganic species (e.g., sodium and chloride) to be negligible in the particle phase. Most aerosol nitrates were organic during SOAS (Lee et al., 2016). After the classification, species volume fractions are estimated from the mass concentrations assuming densities of the species listed in Table 1 .

\subsection{HTDMA measurements and hygroscopicity analysis}

An HTDMA was used to measure water uptake of ambient aerosol at subsaturated conditions (Brechtel and Kreidenweis, 2000). The initial sample air was dried with a Nafion drier to $\mathrm{RH}<30 \%$ and then neutralized with a bipolar $\mathrm{Po}^{210}$ charger. After that a monodisperse aerosol distribution was selected with the first DMA (DMA1, high flow, custom-made, closed loop sheath flow system). Then the selected particle population was exposed to a high, fixed $\mathrm{RH}=90 \pm 3 \%$ and entered the second DMA (DMA2) that was operated as a scanning mobility particle sizer (SMPS). The residence time of the particles in the humidified conditions was about $8 \mathrm{~s}$. The DMA2 was controlled with an adjustable voltage control $(0-10 \mathrm{kV})$ and particle number concentration was measured with a CPC as a function of DMA2 voltage (scanning time of $3 \mathrm{~min}$ ).

The hygroscopic growth factors (GF, the ratio between humidified and dry particle diameter) were calculated at actual $\mathrm{RH}$ and only the data when $\mathrm{RH}=90 \pm 3 \%$ were analyzed. The GF data were corrected to fixed $\mathrm{RH}=90 \%$. Probability density functions of the HTDMA measurements (GF-PDF) were evaluated by using the TDMAinv inversion toolkit (Gysel et al., 2009). In the analysis of ABI, HTDMA and AMS data, only the time periods corresponding to unimodal GFPDF curves were taken into account to prevent including data from externally mixed aerosols in the analysis. Excluding the externally mixed cases in the ABI data analysis simplifies the bounce data interpretation, as it rules out the possibility of mixture of particles having different bounce characteristics (i.e., one solid phase which is bouncing and one liquid phase which is sticking).

Hygroscopicity $\kappa$ was calculated by using (RH, GF) data according to Eq. (11) in Petters and Kreidenweis (2007):

$\kappa_{\mathrm{tot}}=1-\mathrm{GF}^{3}+\frac{\mathrm{GF}^{3}-1}{\frac{\mathrm{RH}}{100 \%}} e^{\left(\frac{4 \sigma_{\mathrm{W}} M_{\mathrm{W}}}{R T \rho_{\mathrm{w}} d_{\mathrm{p}} \mathrm{GF}}\right)}$

with size-selected dry diameter of the particles $d_{\mathrm{p}}$, surface tension of water $\sigma_{\mathrm{w}}=0.072 \mathrm{~J} \mathrm{~m}^{-2}$, temperature $T=297 \mathrm{~K}$, molecular weight of water $M_{\mathrm{w}}=0.018 \mathrm{~kg} \mathrm{~mol}^{-1}$, gas constant $R=8.3145 \mathrm{~J} \mathrm{~mol}^{-1} \mathrm{~K}^{-1}$, and density of water $\rho_{\mathrm{w}}=$ $1000 \mathrm{~kg} \mathrm{~m}^{-2}$.

The hygroscopicity of the organic fraction $\left(\kappa_{\mathrm{OA}}\right)$ was calculated from total hygroscopicity $\left(\kappa_{\text {tot }}\right)$ measured by the HTDMA using a $\kappa$-mixing rule (Petters and Kreidenweis, 2007). In general, hygroscopicity of multicomponent aerosol particles can be estimated as a sum of contributions of each component (Petters and Kreidenweis, 2007). Thus, the mixing rule (Eq. 2) can be separated into the organic (OA) fraction and inorganic (inorg) part (Eq. 3) and the inorganic part can be divided further as (Eq. 4):

$$
\begin{aligned}
\kappa_{\mathrm{tot}}= & \sum_{i=1}^{n} f_{i} \kappa_{i} \\
= & f_{\mathrm{OA}} \kappa_{\mathrm{OA}}+f_{\mathrm{inorg}} \kappa_{\mathrm{inorg}} \\
= & f_{\mathrm{OA}} \kappa_{\mathrm{OA}}+f_{\mathrm{AS}} \kappa_{\mathrm{AS}}+f_{\mathrm{ABS}} \kappa_{\mathrm{ABS}}+f_{\mathrm{SA}} \kappa_{\mathrm{SA}} \\
& +f_{\mathrm{AN}} \kappa_{\mathrm{AN}},
\end{aligned}
$$

where $f_{i}$ and $\kappa_{i}$ are the volume fraction and hygroscopicity parameter of component $i$, respectively (Petters and Kreidenweis, 2007). The volume fractions of organic and inorganic species, i.e., AS, ABS, SA and ammonium nitrate (AN), are derived from AMS mass fractions using densities shown in Table 1. The hygroscopicities of inorganic species were calculated with the E-AIM model (see Table 1) (Clegg et al., 
1998). The residual water associated with SA at dry conditions (i.e., conditions after the diffusion dryer) was taken into account in the data analysis and was calculated with the EAIM as well.

\subsection{Potential aerosol mass oxidation flow reactor (OFR)}

An oxidation flow reactor (OFR) was used during SOAS to investigate OA formation/aging from ambient air on the phase state of the particle over a wide range of $\mathrm{OH}$ exposures $\left(10^{10}-10^{13}\right.$ molec $\left.\mathrm{cm}^{-3} \mathrm{~s}\right)$. The OFR is a cylindrical vessel ( $\sim 13 \mathrm{~L}$ ) with flow of $3.5-4.2 \mathrm{~L} \mathrm{~min}^{-1}$ and gas-phase residence time of approximately $200 \mathrm{~s}$. RH and $T$ inside the OFR were not actively controlled but rather determined by the ambient air sampled without drying. The OFR was mounted on the roof of a measurement trailer.

$\mathrm{OH}$ radicals are generated when the UV lights initiate $\mathrm{O}_{2}$, $\mathrm{H}_{2} \mathrm{O}$ and $\mathrm{O}_{3}$ photochemistry. The variation of $\mathrm{OH}$ radical concentration was achieved by varying the voltage of two UV lamps, which were mounted in Teflon tubes inside the OFR. For the conditions of the SOAS study, oxidation has been shown to be dominated by $\mathrm{OH}$, while nontropospheric chemistry in the reactor is negligible (Peng et al., 2016). The $\mathrm{OH}$ exposure $\left(\mathrm{OH}_{\mathrm{exp}}\right)$ was calculated by the real-time decay of $\mathrm{CO}$ injected into the OFR (1-2 ppm; OH reactivity $\approx 5-$ $\left.10 \mathrm{~s}^{-1}\right)$.

During the last 2 weeks of the campaign, the ABI and AMS were sampling through the OFR, whereas the HTDMA was measuring ambient air throughout the campaign. Both AMS and ABI had separate valve systems to multiplex sampling between OFR and bypass in 10 min steps. The sampling line between the OFR and ABI was approximately $12 \mathrm{~m}$ long copper tubing, whereas all the other inlet lines (i.e., for HTDMA, AMS and ABI bypass) were approximately $3 \mathrm{~m}$ long. However, the tubing diameters were chosen such that the residence time in both tubings were approximately $5 \mathrm{~s}$.

\subsection{Description of structural equation modeling (SEM)}

SEM is a series of statistical methods that allow complex relationships between one or more independent variables and one or more dependent variables (see e.g., Kline, 2015). SEM is most commonly thought of as a combination of factor analysis, multiple regression analysis and analysis of variance (ANOVA). It is used to analyze the structural relationship between measured variables and latent constructs and it estimates the multiple and interrelated dependence in a single analysis. It can be remarked that the SEM allows one to perform some type of multilevel regression/ANOVA on factors. The SEM model used in this study can be categorized as path analysis or more specifically a model of causal interference (Pearl, 2009). Causal models are usually presented as directed acyclic graphs, where the nodes represent the variables and the edges represent the causal relationship so that the arrow shows the direction of the effect (Karvanen, 2015). A graphical model visualizes the causal relationships and is a mathematically well-defined object from where causal conclusions can be drawn in a systematic way. The model in this study is built to describe the factors affecting BF in the measurement data and their internal relationships. The analyses were performed with PROC CALIS in SAS 9.4 software (SAS Institute, Cary, NC).

\section{Results}

The time series of particle hygroscopicity and total particulate mass $\left(\mathrm{PM}_{1}\right)$ and composition measured by HTDMA and AMS, respectively, as well as weather parameters $(T, \mathrm{RH}$, radiation) measured during the SOAS campaign are shown in Fig. 1. All the data are averaged over $10 \mathrm{~min}$ intervals and time periods (shorter than $1 \mathrm{~h}$ ) where missing data are linearly interpolated. The periods where precipitation was more than $3 \mathrm{~mm}$ over $3 \mathrm{~h}$ have been removed from the data analysis. $T, \mathrm{RH}$ and $\mathrm{PM}_{1}$ are shown in Fig. 1a. The background color of Fig. 1a represents solar radiation measured at ground level at the site. Both $T$ (red line in Fig. 1a) and $\mathrm{RH}$ (blue line) were relatively high during the campaign and have strong diurnal variations as expected. Total $\mathrm{PM}_{1}$ (black line) was in the range of $1-10 \mu \mathrm{g} \mathrm{m}^{-3}$ most of the time. The time series of composition of the particles calculated as described in Sect. 2.2. is shown in Fig. $1 \mathrm{~b}$ and the overall mean values are presented in a pie chart next to the plot. OAs (mean mass fraction $67 \%$ ) dominated the $\mathrm{PM}_{1}$ but especially the contribution of ammonium bisulfate (ABS, mean mass fraction $25 \%$ ) increased at times. Apart from a few mornings the estimated SA concentration was low and had a campaign mean value of $7 \%$. The contribution of AS was low during the entire campaign $(<1 \%)$. According to the studies by $\mathrm{Kim}$ et al. (2015), Hu et al. (2015) and Xu et al. (2015), OA is dominated by isoprene and monoterpene SOA, with smaller contributions from anthropogenic and biomass burning sources.

The measured inorganic and organic fractions and the $\kappa$ mixing rule (see Eq. 4) are used to estimate hygroscopicity for organic fraction of the particles, $\kappa_{\mathrm{OA}}$. Total hygroscopicity, $\kappa_{\text {tot }}$, derived from HTDMA measurements at $\mathrm{RH}=90 \pm 3 \%$ is shown in Fig. 1c. $\kappa_{\text {tot }}$ is in the range of $0.1-0.4$, whereas $\kappa_{\mathrm{OA}}$ varies between 0 and 0.3 . As expected, the $\kappa_{\text {tot }}$ is highest when the fraction of organics is lowest. Nevertheless, increasing $\kappa_{\text {tot }}$ cannot be explained only by the increased fraction of inorganics as the $\kappa_{\mathrm{OA}}$ also peaked at the same time implying a more hygroscopic OA (Jimenez et al., 2009; Massoli et al., 2010). $\kappa_{\mathrm{OA}}$ and $\kappa_{\text {tot }}$ are consistent with other studies conducted during the SOAS campaign in the southeastern US (Nguyen et al., 2014; Cerully et al., 2015; Brock et al., 2016).

Diurnal profiles of key parameters are shown in Fig. 2. The data shown in Fig. 2 are averaged over 30 min periods. Quartiles $\left(q_{25} \%\right.$ and $\left.q_{75} \%\right)$ of the $30 \mathrm{~min}$ averages are added to 


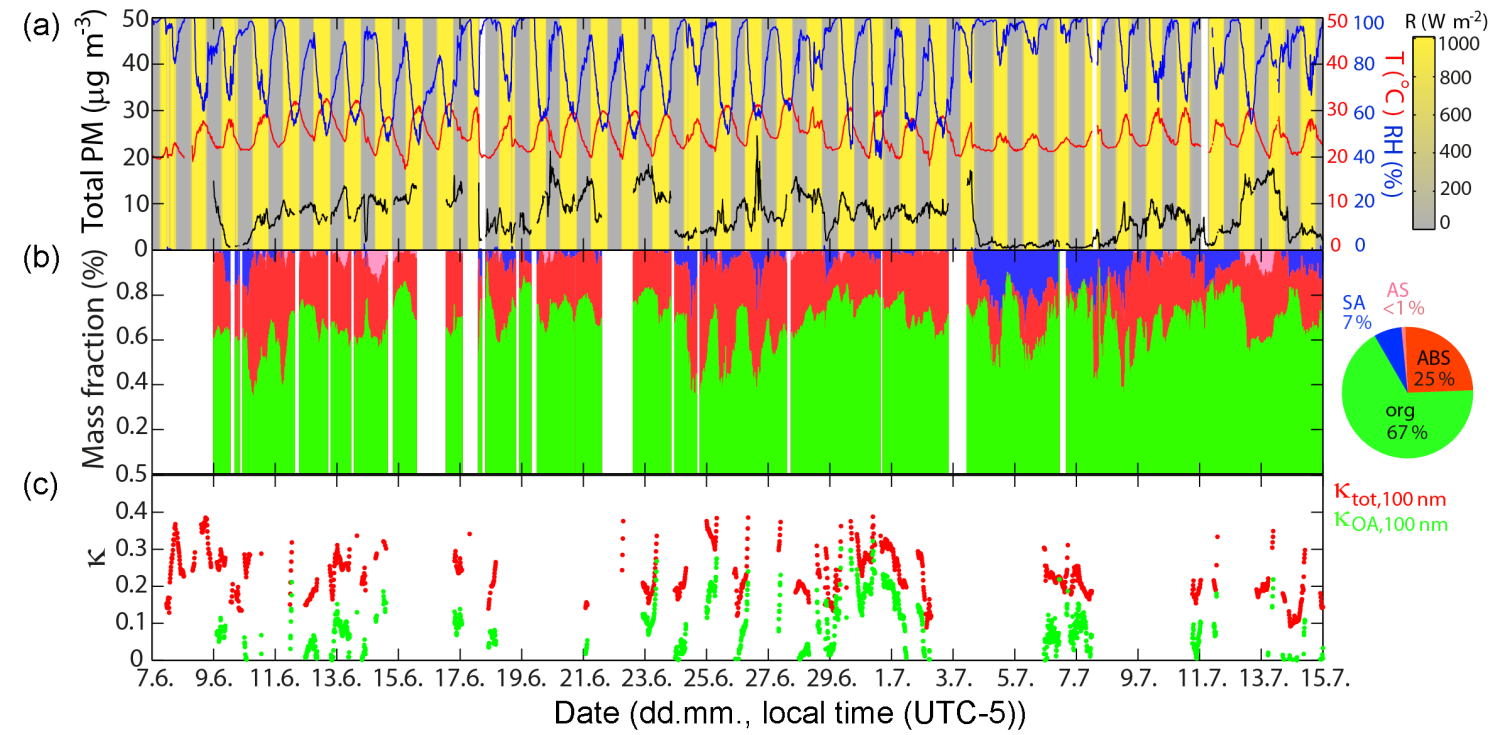

Figure 1. Time series of (a) ambient temperature, RH and $\mathrm{PM}_{1}$ for the entire campaign; (b) mass fraction of OA (green, average $67 \%$ ) and stacked mass fractions of inorganics (blue, pink and red; note that blue represents sulfuric acid instead of the usual nitrate in the AMS color scheme); (c) hygroscopicity $\kappa$ of total particles (red dots) and of OA fraction (green dots). Shaded color in panel (a) represents amount of solar radiation (dark bars denote night and yellow bars denote daytime).

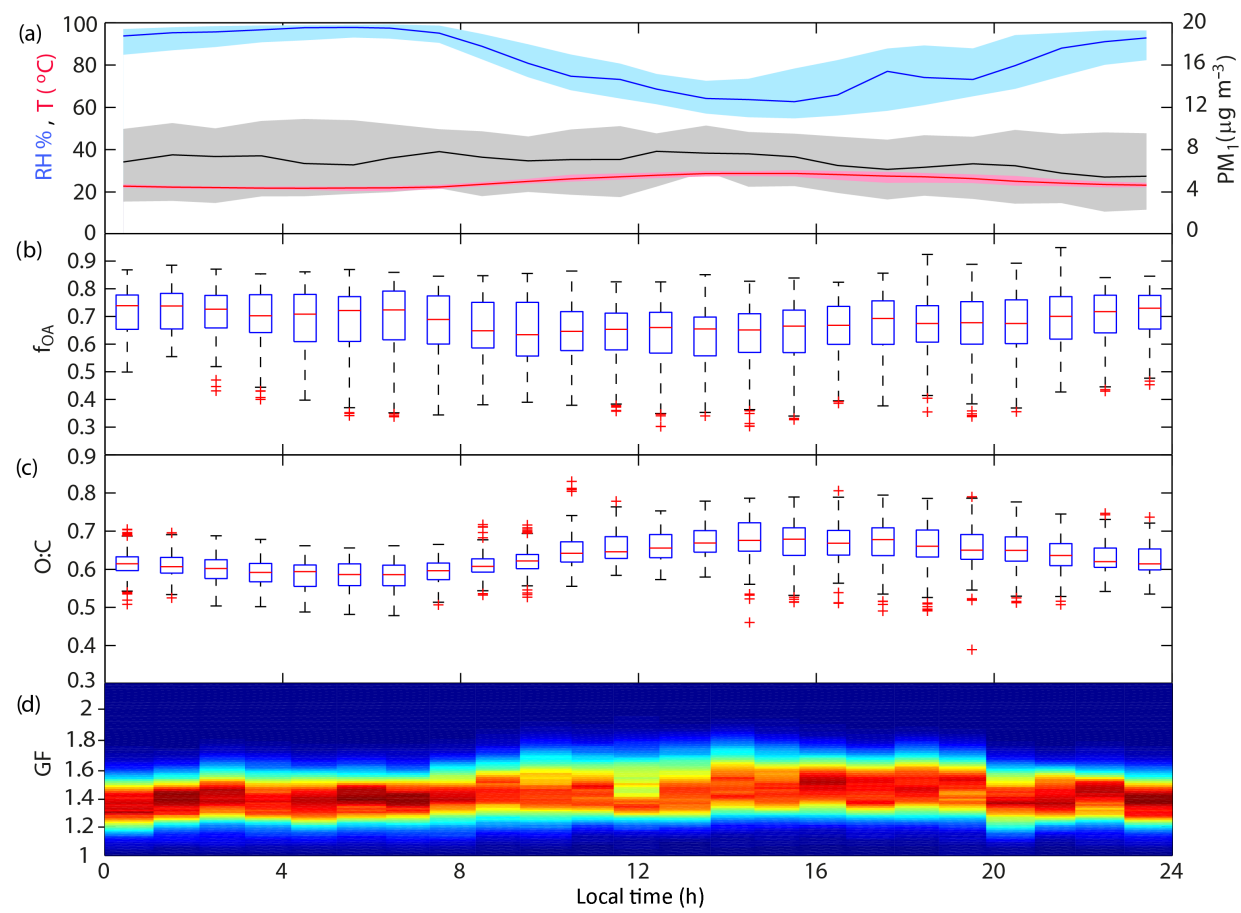

Figure 2. Diurnal profiles of (a) ambient temperature $\left({ }^{\circ} \mathrm{C}\right), \mathrm{RH}(\%)$ and $\mathrm{PM}_{1}\left(\mu \mathrm{g} \mathrm{m}^{-3}\right)$; (b) mass fraction of organics of the ambient particles $\left(f_{\mathrm{OA}}\right)$; (c) degree of oxidation $(\mathrm{O}: \mathrm{C})$; and (d) median of the hygroscopic growth GF-PDF distributions (GF). Shaded areas in panel (a) and blue boxes in panels $(\mathbf{b}, \mathbf{c})$ represent quartiles $\left(q_{25} \%\right.$ and $\left.q_{75} \%\right)$ of the data which are averaged over 30 min intervals. Black error bars represent data range calculated based on the distance to the quartiles $\left(q_{75 \%}-1.5\left(q_{75} \%-q_{25} \%\right) \leq x \leq q_{25} \%-1.5\left(q_{75} \%-q_{25} \%\right)\right.$. Data extremes (outside the error bars) are separated from the data and shown as red crosses. 


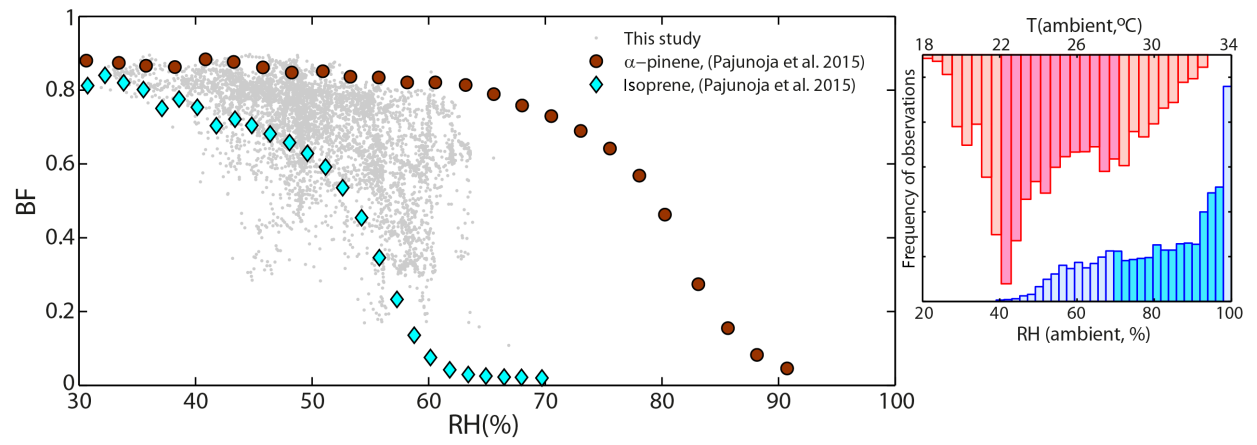

Figure 3. Bounced fraction of the ambient SOA particles vs. fixed RH in the ABI impactor (left). The bounce data (10 min averages) are shown (grey dots) with laboratory results recently reported by Pajunoja at al. (2015) for $\alpha$-pinene ozonolysis SOA (dark brown circles, O : C 0.56 ) and isoprene-derived SOA (light blue diamonds, $\mathrm{O}: \mathrm{C}$ 1.07). Ambient conditions during the campaign ( $T$; red bars and RH; blue bars) are shown in the subplot on the right-hand side where the darker bars represent data within quartiles $\left(q_{25} \%\right.$ and $\left.q_{75} \%\right)$. As can be seen, $75 \%$ of time of the campaign, $\mathrm{RH}_{\text {ambient }}$ was greater than $70 \% \mathrm{RH}$ and $T_{\text {ambient }}>22^{\circ} \mathrm{C}$.

Fig. 2a with shaded color. Both $T$ and RH have typical diurnal profiles: RH drops in the early afternoon, when $T$ reaches its daily maximum. At nighttime, $T$ stays typically above $20^{\circ} \mathrm{C}$, while $\mathrm{RH}$ is near the saturation point. $\mathrm{PM}_{1}$ (Fig. 2a) is rather constant during the day and night. In Fig. $2 \mathrm{~b}$ and c, the median values of $f_{\mathrm{OA}}$ and $\mathrm{O}: \mathrm{C}$ are shown. Hygroscopicity growth factor (GF at $90 \% \mathrm{RH}$ ) data are also averaged over 30 min intervals and is shown in Fig. 2d. The diurnal profile of OA fraction has an opposite trend to that of the GF distributions; the mean GF increases as $f_{\mathrm{OA}}$ decreases, which is not surprising as generally the atmospheric inorganic species are more hygroscopic than SOA (Petters and Kreidenweis, 2007). On the other hand, the diurnal profiles of GF and $\mathrm{O}$ : $\mathrm{C}$ showed similar trends; at nighttime the mean GF was at the lowest range, whereas at daytime they increase together. This also suggests that the increase in total hygroscopicity in daytime partly resulted from increased oxidation of the OA and not only from increased inorganic fraction. However, the $\mathrm{O}: \mathrm{C}$ of the particles peaked in the afternoon but its diurnal profile does not follow exactly the same profile as the GF distributions which reach a maximum approximately $2 \mathrm{~h}$ earlier.

The measured BF plotted as a function of impactor RH of the ABI is shown in Fig. 3. Generally, the data spread over a relatively wide range of $\mathrm{BF}$ and the variation of $\mathrm{BF}$ depends strongly on $\mathrm{RH}$. At $\mathrm{RH}<40 \%$ all measured values show high bounce, indicating a semisolid or solid phase state of the particles. No evidence of liquid particles at these relatively dry conditions was found. As RH increases, the scatter in $\mathrm{BF}(\mathrm{RH})$ increases due to the variations in particle composition. The relationship between the composition and bounce behavior is discussed in more detail in Sect. 3.2. Generally, the bounce started to decrease at RH values approaching $40-60 \%$ at the latest, indicating an early stage of the transition from semisolid to liquid phase. Frequency histograms of ambient $T$ and ambient $\mathrm{RH}$ are added to Fig. 3 as a subplot. When considering the ambient humidity con- ditions at the measurement site (see subplot in Fig. 3; RH varying mostly between 70 and $100 \%$ ), our results indicate that organic-dominated aerosol particles are mostly in the liquid phase during the summer season in the southeastern US. However, as ambient RH typically drops during afternoons and if the OA fraction is high enough, the particles can be in a semisolid phase under such atmospheric conditions. Such a clear difference in BF between dry and ambient RH indicates the possibility that the aerosol particles may undergo phase transition from liquid to semisolid when dried in any sampling system. This could cause measurement error when investigating, for instance, evaporation/condensation, chemical reactivity or volatility.

As discussed above, the OA at the SOAS site is dominated by isoprene- and monoterpene-SOA. Results from Pajunoja et al. (2015) for SOA stemming from ozonolysis of $\alpha$-pinene and isoprene are added to Fig. 3 to illustrate a typical bounce behavior of pure laboratory SOA. As can be seen, the major fraction of the ambient measurements falls between the $\mathrm{BF}$ curves measured for isoprene SOA with $\mathrm{O}: \mathrm{C} 1.07$ and monoterpene ( $\alpha$-pinene derived) SOA with O : $\mathrm{C} 0.56$ showing that the ambient observations are consistent with the laboratory studies.

\subsection{Link between hygroscopicity, oxidation level and phase state}

To investigate how the particle phase state, hygroscopicity and degree of oxidation are linked, we combined the data measured by ABI, HTDMA and AMS. Bounce behavior is sensitive to $\mathrm{RH}$ in the range where the particles undergo humidity-induced phase transition as water acts as a plasticizer. For this reason, even small changes in RH cannot be ignored in the analysis. To analyze the phase change and factors affecting it, we plot $(\mathrm{RH}, \mathrm{BF})$ scatterplots where the values of $f_{\mathrm{OA}}, \kappa_{\text {tot }}, \mathrm{O}: \mathrm{C}$ and $\kappa_{\mathrm{OA}}$ are represented by color coding (Fig. 4). The (RH, BF) area is divided into pixels, 1 

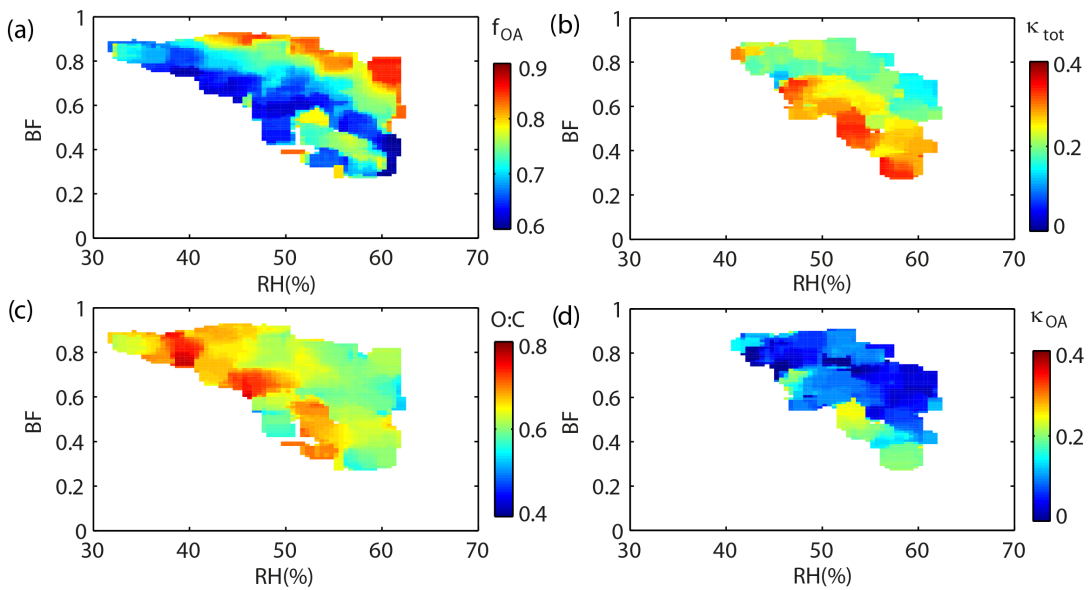

Figure 4. Comparison between BF, impactor RH and particle properties for ambient-only data; (a) (RH, BF) data colored with fraction of organics derived from AMS analysis, (b) $(\mathrm{RH}, \mathrm{BF})$ data colored with hygroscopicity- $\kappa$ derived from HTDMA results, (c) (RH, BF) data colored with O : C (Canagaratna et al., 2015) derived from AMS analysis and (d) (RH, BF) data colored with hygroscopicity $\kappa$ of the OA fraction of the particles derived from HTDMA and AMS results. Data are filtered by $f_{\mathrm{OA}} \geq 0.6$ and precipitation $<1 \mathrm{~mm} \mathrm{~h}^{-1}$.

pixel being $0.5 \% \mathrm{RH}$ wide and 0.02 high. The value of each pixel represents the average of all the data in the pixel. To isolate the effect of OA fraction on the phase state and to exclude the rainy periods, we have filtered the data to in-

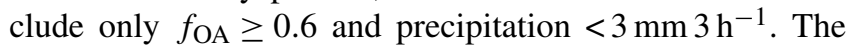
same filter is used also in Sect. 3.2. All particles behave like solids/semisolids at $\mathrm{RH}<40 \%$ but as $\mathrm{RH}$ increases, BF drops to an extent that depends on the chemical composition and hygroscopicity of the particles. Typically, the particles with the highest organic fraction (see Fig. 4a; dark red, $f_{\mathrm{OA}}>0.8$ ) bounce even at high $\mathrm{RH}$ (range of $\mathrm{RH}$ ) indicating semisolid phase of the OA fraction. At the same time $\kappa_{\text {tot }}, \mathrm{O}: \mathrm{C}$ and $\kappa_{\mathrm{OA}}$ have the lowest values (see Fig. $4 \mathrm{~b}-$ d). Hence, the observation is in agreement with laboratory results showing that an increase in $\mathrm{O}: \mathrm{C}$ of SOA particles decreases the particle liquefying RH (Pajunoja et al., 2015; Saukko et al., 2012). This is due to the low water uptake of the less-oxidized organic material in the particles.

Saukko et al. (2015) showed that in the case of mixed ammonium sulfate and $\alpha$-pinene derived OA with relatively low $\mathrm{O}: \mathrm{C}$ and thus separated phases of $\mathrm{OA}$ and inorganic fractions, the particle bounce was greatly affected by the organic fraction when the organic mass fraction was $\geq 0.7$. In their study, it was shown that the particle bounce started to increase with solidification of the organic fraction even if the inorganic core was deliquesced. This leads to the conclusion that the bounce behavior of mixed particles is dominated by organic material when $f_{\mathrm{OA}} \geq 0.7$. Most of the data points existing below the BF curve of isoprene SOA in Fig. 3 (blue diamonds) were dominated by inorganics and thus are not represented in Fig. 4a due to the filtering of the data with $f_{\mathrm{OA}} \geq 0.6$.

When the most hygroscopic particles are investigated (red area in Fig. 4b), the phase transition from semisolids to liq- uids starts already at $\mathrm{RH}=40-50 \%$. From Fig. $4 \mathrm{a}-\mathrm{c}$ it can be seen that particles having the highest hygroscopicity and also the lowest bounce at elevated humidity have the highest inorganic fraction and also the highest $\mathrm{O}: \mathrm{C}$ of the organic fraction resulting in the highest $\kappa_{\mathrm{OA}}$. Hence, the high values of $\kappa_{\mathrm{tot}}$ result from the high fraction of inorganics and also high $\kappa_{\mathrm{OA}}$, and the phase change at relatively low humidities is driven by the water uptake of both organic and inorganic fractions. The inorganic fraction consists mostly of ABS having DRH and ERH values lower than $40 \%$ RH (see Table 1). This allows us to assume that the inorganic fraction is always deliquesced at $\mathrm{RH}$ used in the ABI. The sensitivity of the method to calculate $\kappa_{\mathrm{OA}}$ was also tested by varying $f_{\mathrm{AS}}$, $f_{\mathrm{ABS}}$ and $f_{\mathrm{SA}}$. In more than $95 \%$ of the cases, the spread in $\kappa_{\mathrm{OA}}$ is less than 0.04 , and it does not change the trends in Fig. 4d.

Based on the data presented in Fig. 4, we can conclude that the particle phase state is affected both by the contribution of inorganic fraction and the organic fraction. The SEM analysis also supports the conclusions made based on Fig. 4. SEM was used to investigate relationships between (RH, BF) pairs and the key variables shown in Fig. 4. In addition to the key variables, ambient $T$ ( $\left.T_{\text {ambient }}\right)$ and ambient $\mathrm{RH}\left(\mathrm{RH}_{\text {ambient }}\right)$ were added to the model since they affect the results mainly by affecting the inlet conditions of ABI (and thus affecting the fixed RH inside the ABI). The SEM results of the ambient data shown in Fig. 4 are listed in Tables 2 and S1 (see Supplement). Table 2 shows the total, direct and indirect effects of the predictor variables on BF, and Table S1 describes the magnitudes of individual parameter estimates within the pathway model. Indirect effect can be described such that when, e.g., $\kappa_{\mathrm{OA}}$ has a significant effect on $\kappa_{\text {tot }}$ (see Table S1), which in turn affects $\mathrm{BF}$, the $\kappa_{\mathrm{OA}}$ has an "effect pathway" to $\mathrm{BF}$ via $\kappa_{\text {tot }}$, and magnitude of this effect can be quanti- 
Table 2. Standardized effects (direct, indirect and total) on BF based on the SEM model performed for ambient data (Fig. 4) and OFR data (Fig. 5). Effects are standardized (i.e., scaled to follow normal distribution with zero mean and variance of unity) in order to compare parameter values that are measured on quite different scales.

\begin{tabular}{|c|c|c|c|c|c|c|c|}
\hline \multirow[b]{2}{*}{ Parameter } & & \multicolumn{3}{|c|}{ AMBIENT } & \multicolumn{3}{|c|}{ OFR } \\
\hline & & Total & Direct & Indirect & Total & Direct & Indirect \\
\hline \multirow[t]{2}{*}{ RH } & Effect & -0.66 & -0.66 & 0 & -0.5 & -0.5 & 0 \\
\hline & SE & 0.02 & 0.02 & & 0.02 & 0.02 & \\
\hline \multirow[t]{2}{*}{$f_{\mathrm{OA}}$} & Effect & 0.14 & 0 & 0.14 & 0.61 & 0.52 & 0.09 \\
\hline & SE & 0.02 & & 0.02 & 0.02 & 0.03 & 0.01 \\
\hline \multirow[t]{2}{*}{$\mathrm{O}: \mathrm{C}$} & Effect & -0.22 & -0.16 & -0.06 & -0.3 & -0.25 & 0 \\
\hline & $\mathrm{SE}$ & 0.03 & 0.02 & 0.02 & 0.03 & 0.03 & \\
\hline \multirow[t]{2}{*}{$T_{\text {ambient }}$} & Effect & 0.19 & 0 & 0.19 & 0.24 & 0 & 0.24 \\
\hline & SE & 0.03 & & 0.03 & 0.02 & & 0.02 \\
\hline \multirow{2}{*}{$\mathrm{RH}_{\mathrm{ambient}}$} & Effect & -0.35 & -0.17 & -0.17 & & $\mathrm{n} / \mathrm{a}$ & \\
\hline & SE & 0.04 & 0.03 & 0.04 & & & \\
\hline \multirow[t]{2}{*}{$\kappa_{\text {tot }}$} & Effect & -0.5 & -0.5 & 0 & & $\mathrm{n} / \mathrm{a}$ & \\
\hline & SE & 0.02 & 0.02 & & & & \\
\hline \multirow{2}{*}{$\kappa_{\mathrm{OA}}$} & Effect & -0.49 & 0 & -0.49 & & $\mathrm{n} / \mathrm{a}$ & \\
\hline & SE & 0.02 & & 0.02 & & & \\
\hline \multirow[t]{2}{*}{$\log _{10}(\mathrm{OH})$} & Effect & & $\mathrm{n} / \mathrm{a}$ & & -0.5 & -0.11 & -0.4 \\
\hline & SE & & & & 0.03 & 0.02 & 0.02 \\
\hline \multirow[t]{2}{*}{$f_{\mathrm{ABS}}$} & Effect & & $\mathrm{n} / \mathrm{a}$ & & -0.3 & 0 & -0.25 \\
\hline & SE & & & & 0.02 & & 0.02 \\
\hline
\end{tabular}

fied into the indirect effect shown in Table 2. Table 2 shows that $\mathrm{RH}$ and $\kappa_{\text {tot }}$ have a direct effect to $\mathrm{BF}$ while $\kappa_{\mathrm{OA}}$ and $f_{\mathrm{OA}}$ have indirect effects via $\kappa_{\text {tot }} . \mathrm{O}: \mathrm{C}$ has both direct and indirect (via $\kappa_{\mathrm{OA}}$ ) effects on $\mathrm{BF}$. $\mathrm{RH}_{\mathrm{ambient}}$ can be interpreted as an indicator of local meteorology and diurnal variation. $T_{\text {ambient }}$ in turn has an effect on $\mathrm{RH}$ and thus has an indirect effect on BF. Based on the data listed in Tables 2 and S1, we can conclude that $\kappa_{\text {tot }}$ has the biggest influence on BF and that $f_{\mathrm{OA}}$ is affecting $\mathrm{BF}$ indirectly via hygroscopicities.

\subsection{Effect of particle oxidation in OH-OFR on bounce behavior}

The degree of oxidation of ambient OA particles can be enhanced with an OH-OFR flow reactor. The reactor was used for 2 weeks (from 1 to 15 July) to study the effect of the increased oxidation of ambient particles on their bounce behavior. Again, only the cases where the organic fraction of initial ambient aerosol (measured via the bypass) was greater than 0.6 were considered in the analysis. In Fig. 5, the measured bounced fraction as a function of relative humidity of the humidification system is depicted. The data are colored by $\mathrm{OH}$ exposure (Fig. 5a), OA fraction (Fig. 5b), O : C of the organics (Fig. 5c) and fraction of ammonium bisulfate (Fig. 5d). In general, ABS formed the major fraction of the inorganics.

During the measurement period, the $\mathrm{O}: \mathrm{C}$ of ambient aerosol was $0.5-0.9$ for the analyzed cases. When the aerosol was exposed to increased $\mathrm{OH}$ concentration in the OFR the $f_{\mathrm{OA}}$ as well as the $\mathrm{O}: \mathrm{C}$ increased when the $\mathrm{OH}$ exposure was small. With the very high $\mathrm{OH}$ exposure values $(\mathrm{OH}$ exposure $>3-10 \times 10^{12}$ molecules $\mathrm{cm}^{-3} \mathrm{~s}^{-1}$ ) $\mathrm{O}: \mathrm{C}$ reached very high values (maximum approximately 1.8 ) but at the same time $f_{\mathrm{OA}}$ decreased. These data points are marked in red color in Fig. 5a, c and d and in blue color in Fig. 5b. The increase of the $\mathrm{O}: \mathrm{C}$ up to very high values and simultaneous decrease of $\mathrm{OA}$ fraction is probably due to the strong heterogeneous fragmentation/volatilization of the particulate organic molecules (Ortega et al., 2016; Palm et al., 2016).

When the $\mathrm{O}: \mathrm{C}$ of the particles exposed to elevated $\mathrm{OH}$ concentration was at the same level as the $\mathrm{O}: \mathrm{C}$ of ambient particles (see Figs. 4a-d and 6), the bounce behavior was very similar for both ambient and $\mathrm{OH}$-aged aerosol. As can be expected when the $\mathrm{O}: \mathrm{C}$ further increased due to the elevated $\mathrm{OH}$ exposure in OFR, the BF measured at certain RH conditions clearly decreased with increasing $\mathrm{O}: \mathrm{C}$. The trend is similar to ambient data as can be seen in Fig. 6 where the BF for ambient after OFR treatment and corresponding ambient-only data are presented for selected narrow $\mathrm{RH}$ range $(48 \pm 4 \% \mathrm{RH})$ and for particles having $f_{\mathrm{OA}}$ greater than 0.6 after the treatment. The data indicate that the highly oxidized particles may undergo an early stage of the phase transition already at $\mathrm{RH}<40 \%$. It is possible that detected changes in BF with increasing $\mathrm{O}: \mathrm{C}$ can be affected also by the morphological changes of particles. According to Bertram et al. (2011), the particles consisting of inorganic sulfate fraction and organic fraction with $\mathrm{O}: \mathrm{C}<0.7$ undergo liquid-liquid phase separation (LLPS) while particles having $\mathrm{O}: \mathrm{C}>0.7$ exist in one mixed phase. Also, the deliques- 

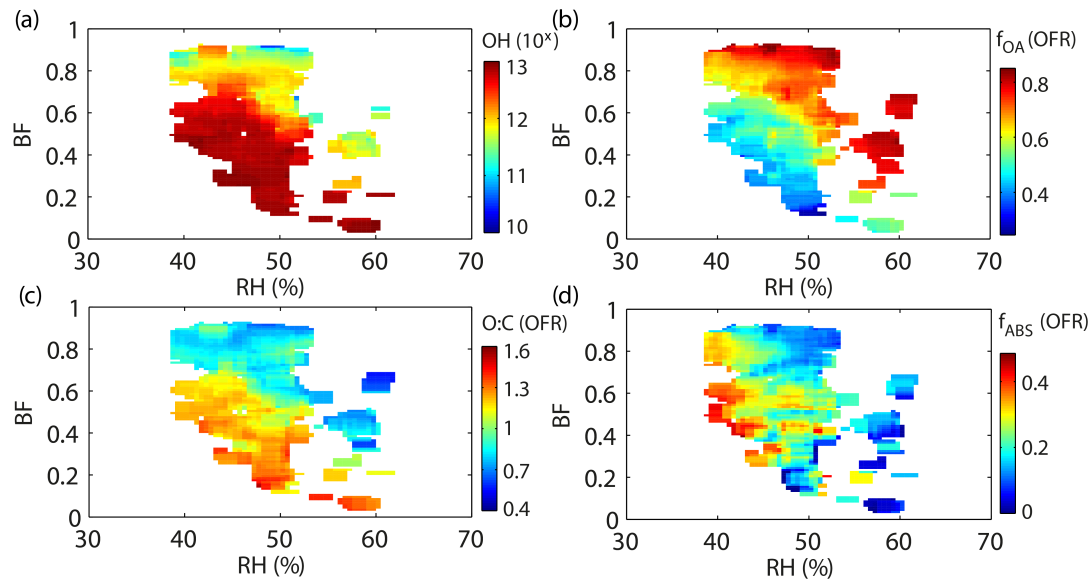

Figure 5. Scatterplot between BF, impactor RH and particle properties measured through the OFR; (a) (RH, BF) data colored with exposed $\mathrm{OH}$ concentration $\left(10^{x}\right.$ molec $\left.\mathrm{cm}^{-3} \mathrm{~s}\right)$, (b) (RH, BF) data colored with organic mass fraction of the particles derived from AMS results, (c) $(\mathrm{RH}, \mathrm{BF})$ data colored with $\mathrm{O}: \mathrm{C}$ derived from AMS analysis, (d) (RH, BF) data colored with mass fraction of ammonium bisulfate derived from AMS analysis and composition categorization as in Cerully et al. (2015). Data are filtered by precipitation $<1 \mathrm{~mm} \mathrm{~h}^{-1}$ and ambient aerosols $f_{\mathrm{OA}} \geq 0.6$.

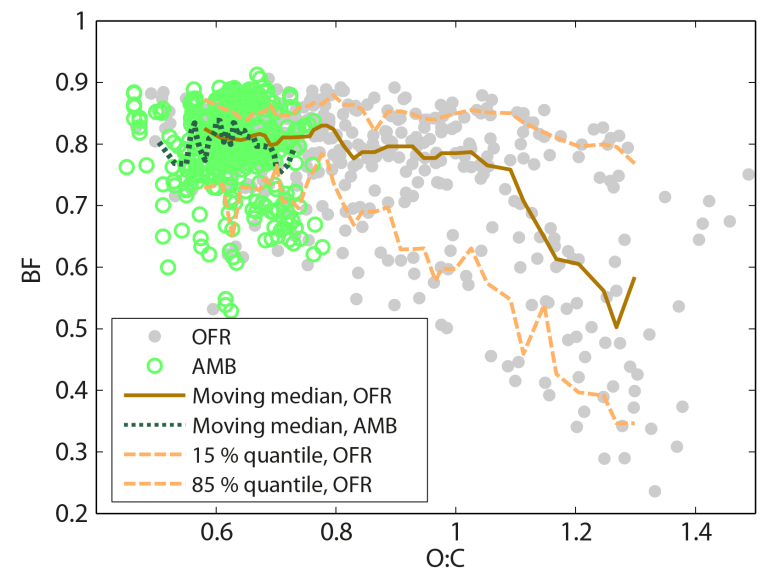

Figure 6. Bounced fraction (BF; $10 \mathrm{~min}$ averages) of the ambient OA (green hollow dots) and corresponding OFR-treated OA (grey dots) vs. degree of oxidation $(\mathrm{O}: \mathrm{C})$. $\mathrm{RH}$ range of the $\mathrm{ABI}$ is limited to $\mathrm{RH}=48 \pm 4 \%$ and only data points where $f_{\mathrm{OA}} \geq 0.6$ after the OFR treatment has used in the analysis. This has done to minimize the effect of RH and inorganics on BF in the figure. Moving median for ambient data (dark green dashed line) and for OFR data (brown line) are added to the figure as well as quantiles of OFR data (light brown dashed lines).

cence RH of inorganic fraction in the mixture particles depends on the both $\mathrm{O}: \mathrm{C}$ of organics and $f_{\mathrm{OA}}$ (Bertram et al., 2011; Smith et al., 2012). Unfortunately, we cannot distinguish the phase separation and fully mixed particles from the data. Nonetheless, to minimize the effect of inorganic fraction on total BF, we narrowed our analysis to include only periods where the organic mass fraction was greater than 0.6.
These conclusions are supported also by the SEM analysis performed for OFR data. Table 2 reports the effects in SEM model built on OFR data and Table S2 (see Supplement) describes the magnitudes of individual parameter estimates within the pathway model. Table 2 shows that $\mathrm{OH}$ concentration has significant decreasing direct and indirect (via $\mathrm{O}: \mathrm{C}$ and $f_{\mathrm{OA}}$ ) effects on $\mathrm{BF}$. $\mathrm{RH}$ and $\mathrm{O}: \mathrm{C}$ have only direct effects and $f_{\mathrm{ABS}}$ has only indirect effect via $f_{\mathrm{OA}}$, which has both direct and indirect (via $\mathrm{O}: \mathrm{C}$ ) effects. $T_{\text {ambient }}$ affects again $\mathrm{RH}$ but the meteorology-indicating effect of $\mathrm{RH}_{\text {ambient }}$ on RH is not anymore significant after OFR treatment. Relationship between $\mathrm{BF}$ and $\mathrm{O}: \mathrm{C}$ is not strong for ambient data but after OFR treatment the relationship between $\mathrm{O}: \mathrm{C}$ and $\mathrm{BF}$ instead is more pronounced, namely that the higher oxidation of OA decreases the semisolidness of the particles. For OFR data, $f_{\mathrm{OA}}$ has negative and $f_{\mathrm{ABS}}$ positive correlation with $\mathrm{O}: \mathrm{C}$ which is due to loss of organics at high $\mathrm{OH}$ exposures.

\section{Conclusions}

Phase state of ambient particles was inferred from ABI measurements conducted at a rural site in central Alabama between 1 June and 15 July 2013 as a part of SOAS campaign. HTDMA was used to measure water uptake of the dried ambient particles at $90 \% \mathrm{RH}$ while AMS was employed to resolve dried $\mathrm{PM}_{1}$ composition and $\mathrm{O}: \mathrm{C}$ of the organic fraction. Organics accounted for $67 \%$ of total $\mathrm{PM}_{1}$ during the campaign. Ammonium bisulfate is estimated to be the main contributor of inorganics with a mean fraction of $25 \%$ while on average only $7 \%$ of the particle mass was sulfuric acid.

Based on ABI measurements, we found that the phase transition from semisolid to liquid phase starts in the $\mathrm{RH}$ 
range from 40 to $60 \%$ depending on the particle composition. Thus, the results indicate that the organic-dominated ambient SOA particles are mostly in the liquid phase in the southeastern US at atmospherically relevant summertime RH conditions but they often turn semisolid when dried in the measurement setup. The RH-dependent bounce curves measured for ambient aerosol having an organic mass fraction $\geq 60 \%$ fall between the BF curves measured for isoprene and monoterpene SOA generated in the laboratory (Pajunoja et al., 2015). This is consistent with the findings by Kim et al. (2015), $\mathrm{Hu}$ et al. (2015) and Xu et al. (2015) that both types of SOA dominate OA composition at this site. The characteristics of the organic fraction such as $\mathrm{O}: \mathrm{C}$ and hygroscopicity played a role in the bounce process; particles with the highest organic fraction, lowest hygroscopicity and/or lowest $\mathrm{O}: \mathrm{C}$ stayed semisolid at higher RH than particles having lower organic fraction and higher hygroscopicity. The statistical SEM analysis revealed that the main factor controlling the liquefying RH of ambient aerosol particles is their hygroscopicity.

Further OH oxidation of SOAs by the OFR provides an extended oxidation range for the analysis. The lowest $\mathrm{OH}$ exposures increased the organic mass and slightly also the degree of oxidation of OAs, whereas the higher $\mathrm{OH}$ exposures resulted in clearly higher $\mathrm{O}: \mathrm{C}$, a loss of organic mass, and hence an increased mass fraction of ABS. According to the bounce measurements, the increased $\mathrm{OH}$ exposure decreased the phase transition RH. This is emphasized at the highest $\mathrm{OH}$ exposures.

Based on the measurements we can conclude that in the isoprene- and terpene-rich environment influenced also by anthropogenic emissions, the atmospheric aerosols dominated by the organic fraction are mostly in the liquid phase when the temperature and $\mathrm{RH}$ conditions are comparable to those in the southeastern US during the summer season. The increased $\mathrm{OH}$ exposure decreased the particle liquefying RH further, implying that any further atmospheric aging of the aerosol does not change the conclusion. The results suggest that in environments similar to the measurement site, it can be assumed that the diffusion limitations in the particle bulk are negligible and the particles can be treated as liquid droplets in regional transport models. The results are in line with the results reported in Amazonia which also represents an isoprene rich environment having elevated RH and temperature conditions (Bateman et al., 2016).

\section{Data availability}

All the measurement data are available upon request from the corresponding author (annele.virtanen@uef.fi).

The Supplement related to this article is available online at doi:10.5194/acp-16-11163-2016-supplement.
Acknowledgements. The authors acknowledge the European Research Council (ERC starting grant 335478), Academy of Finland (259005, 272041), UEF strategic funding. Weiwei $\mathrm{Hu}$, Brett B. Palm and Jose L. Jimenez acknowledge funding from NSF AGS-1243354/AGS-1360834, EPRI 10004734 and DOE (BER/ASR) DE-SC0011105. Don R. Collins and Nathan F. Taylor acknowledge funding from NSF AGS-1242932. Brett B. Palm acknowledges support from a US EPA STAR Graduate Fellowship (FP-91761701-0). The manuscript has not been reviewed by EPA and thus no endorsement should be inferred.

Edited by: M. Shiraiwa

Reviewed by: two anonymous referees

\section{References}

Abramson, E., Imre, D., Beránek, J., Wilson, J., and Zelenyuk, A.: Experimental determination of chemical diffusion within secondary organic aerosol particles, Phys. Chem. Chem. Phys., 15, 2983-2991, doi:10.1039/c2cp44013j, 2013.

Alfarra, M. R., Good, N., Wyche, K. P., Hamilton, J. F., Monks, P. S., Lewis, A. C., and McFiggans, G.: Water uptake is independent of the inferred composition of secondary aerosols derived from multiple biogenic VOCs, Atmos. Chem. Phys., 13, 1176911789, doi:10.5194/acp-13-11769-2013, 2013.

Bateman, A. P., Belassein, H., and Martin, S. T.: Impactor apparatus for the study of particle rebound: Relative humidity and capillary forces, Aerosol Sci. Tech., 48, 42-52, doi:10.1080/02786826.2013.853866, 2014.

Bateman, A. P., Gong, Z., Liu, P., Sato, B., Cirino, G., Zhang, Y., Artaxo, P., Bertram, A. K., Manzi, A. O., and Rizzo, L. V.: Sub-micrometre particulate matter is primarily in liquid form over Amazon rainforest, Nat. Geosci., 9, 34-37, doi:10.1038/NGEO2599, 2016.

Berkemeier, T., Shiraiwa, M., Pöschl, U., and Koop, T.: Competition between water uptake and ice nucleation by glassy organic aerosol particles, Atmos. Chem. Phys., 14, 12513-12531, doi:10.5194/acp-14-12513-2014, 2014.

Bertram, A. K., Martin, S. T., Hanna, S. J., Smith, M. L., Bodsworth, A., Chen, Q., Kuwata, M., Liu, A., You, Y., and Zorn, S. R.: Predicting the relative humidities of liquid-liquid phase separation, efflorescence, and deliquescence of mixed particles of ammonium sulfate, organic material, and water using the organic-to-sulfate mass ratio of the particle and the oxygen-tocarbon elemental ratio of the organic component, Atmos. Chem. Phys., 11, 10995-11006, doi:10.5194/acp-11-10995-2011, 2011.

Brechtel, F. J. and Kreidenweis, S. M.: Predicting particle critical supersaturation from hygroscopic growth measurements in the humidified TDMA. Part I: Theory and sensitivity studies, J. Atmos. Sci., 57, 1854-1871, doi:10.1175/15200469(2000)057<1854:PPCSFH>2.0.CO;2, 2000.

Brock, C. A., Wagner, N. L., Anderson, B. E., Attwood, A. R., Beyersdorf, A., Campuzano-Jost, P., Carlton, A. G., Day, D. A., Diskin, G. S., Gordon, T. D., Jimenez, J. L., Lack, D. A., Liao, J., Markovic, M. Z., Middlebrook, A. M., Ng, N. L., Perring, A. E., Richardson, M. S., Schwarz, J. P., Washenfelder, R. A., Welti, A., Xu, L., Ziemba, L. D., and Murphy, D. M.: Aerosol optical properties in the southeastern United States in summer 
- Part 1: Hygroscopic growth, Atmos. Chem. Phys., 16, 49875007, doi:10.5194/acp-16-4987-2016, 2016.

Budisulistiorini, S. H., Li, X., Bairai, S. T., Renfro, J., Liu, Y., Liu, Y. J., McKinney, K. A., Martin, S. T., McNeill, V. F., Pye, H. O. T., Nenes, A., Neff, M. E., Stone, E. A., Mueller, S., Knote, C., Shaw, S. L., Zhang, Z., Gold, A., and Surratt, J. D.: Examining the effects of anthropogenic emissions on isoprenederived secondary organic aerosol formation during the 2013 Southern Oxidant and Aerosol Study (SOAS) at the Look Rock, Tennessee ground site, Atmos. Chem. Phys., 15, 8871-8888, doi:10.5194/acp-15-8871-2015, 2015.

Canagaratna, M., Jayne, J., Jimenez, J., Allan, J., Alfarra, M., Zhang, Q., Onasch, T., Drewnick, F., Coe, H., and Middlebrook, A.: Chemical and microphysical characterization of ambient aerosols with the aerodyne aerosol mass spectrometer, Mass Spectrom. Rev., 26, 185-222, doi:10.1002/mas.20115, 2007.

Canagaratna, M. R., Jimenez, J. L., Kroll, J. H., Chen, Q., Kessler, S. H., Massoli, P., Hildebrandt Ruiz, L., Fortner, E., Williams, L. R., Wilson, K. R., Surratt, J. D., Donahue, N. M., Jayne, J. T., and Worsnop, D. R.: Elemental ratio measurements of organic compounds using aerosol mass spectrometry: characterization, improved calibration, and implications, Atmos. Chem. Phys., 15, 253-272, doi:10.5194/acp-15-253-2015, 2015.

Cappa, C. D. and Wilson, K. R.: Evolution of organic aerosol mass spectra upon heating: implications for OA phase and partitioning behavior, Atmos. Chem. Phys., 11, 1895-1911, doi:10.5194/acp11-1895-2011, 2011.

Cerully, K. M., Bougiatioti, A., Hite Jr., J. R., Guo, H., Xu, L., Ng, N. L., Weber, R., and Nenes, A.: On the link between hygroscopicity, volatility, and oxidation state of ambient and water-soluble aerosols in the southeastern United States, Atmos. Chem. Phys., 15, 8679-8694, doi:10.5194/acp-15-8679-2015, 2015.

Clegg, S. L., Brimblecombe, P., and Wexler, A. S.: Thermodynamic model of the system $\mathrm{H}-\mathrm{NH}_{4}^{+}-\mathrm{SO}_{4}^{2-}-\mathrm{NO}_{3}^{-}-\mathrm{H}_{2} \mathrm{O}$ at tropospheric temperatures, J. Phys. Chem. A, 102, 2137-2154, doi:10.1021/jp973042r, 1998.

DeCarlo, P. F., Kimmel, J. R., Trimborn, A., Northway, M. J., Jayne, J. T., Aiken, A. C., Gonin, M., Fuhrer, K., Horvath, T., and Docherty, K. S.: Field-deployable, high-resolution, time-offlight aerosol mass spectrometer, Anal. Chem., 78, 8281-8289, doi:10.1021/ac061249n, 2006.

Duplissy, J., DeCarlo, P. F., Dommen, J., Alfarra, M. R., Metzger, A., Barmpadimos, I., Prevot, A. S. H., Weingartner, E., Tritscher, T., Gysel, M., Aiken, A. C., Jimenez, J. L., Canagaratna, M. R., Worsnop, D. R., Collins, D. R., Tomlinson, J., and Baltensperger, U.: Relating hygroscopicity and composition of organic aerosol particulate matter, Atmos. Chem. Phys., 11, 11551165, doi:10.5194/acp-11-1155-2011, 2011.

Ehn, M., Thornton, J. A., Kleist, E., Sipilä, M., Junninen, H., Pullinen, I., Springer, M., Rubach, F., Tillmann, R., and Lee, B.: A large source of low-volatility secondary organic aerosol, Nature, 506, 476-479, doi:10.1038/nature13032, 2014.

Goldstein, A. H., Koven, C. D., Heald, C. L., and Fung, I. Y.: Biogenic carbon and anthropogenic pollutants combine to form a cooling haze over the southeastern United States, P. Natl. Acad. Sci. USA, 106, 8835-8840, doi:10.1073/pnas.0904128106, 2009.

Guenther, A. B., Jiang, X., Heald, C. L., Sakulyanontvittaya, T., Duhl, T., Emmons, L. K., and Wang, X.: The Model of Emissions of Gases and Aerosols from Nature version 2.1 (MEGAN2.1): an extended and updated framework for modeling biogenic emissions, Geosci. Model Dev., 5, 1471-1492, doi:10.5194/gmd-51471-2012, 2012.

Gysel, M., McFiggans, G., and Coe, H.: Inversion of tandem differential mobility analyser (TDMA) measurements, J. Aerosol Sci., 40, 134-151, doi:10.1016/j.jaerosci.2008.07.013, 2009.

Hallquist, M., Wenger, J. C., Baltensperger, U., Rudich, Y., Simpson, D., Claeys, M., Dommen, J., Donahue, N. M., George, C., Goldstein, A. H., Hamilton, J. F., Herrmann, H., Hoffmann, T., Iinuma, Y., Jang, M., Jenkin, M. E., Jimenez, J. L., Kiendler-Scharr, A., Maenhaut, W., McFiggans, G., Mentel, Th. F., Monod, A., Prévôt, A. S. H., Seinfeld, J. H., Surratt, J. D., Szmigielski, R., and Wildt, J.: The formation, properties and impact of secondary organic aerosol: current and emerging issues, Atmos. Chem. Phys., 9, 5155-5236, doi:10.5194/acp-9-51552009, 2009.

Hu, W. W., Campuzano-Jost, P., Palm, B. B., Day, D. A., Ortega, A. M., Hayes, P. L., Krechmer, J. E., Chen, Q., Kuwata, M., Liu, Y. J., de Sá, S. S., McKinney, K., Martin, S. T., Hu, M., Budisulistiorini, S. H., Riva, M., Surratt, J. D., St. Clair, J. M., Isaacman-Van Wertz, G., Yee, L. D., Goldstein, A. H., Carbone, S., Brito, J., Artaxo, P., de Gouw, J. A., Koss, A., Wisthaler, A., Mikoviny, T., Karl, T., Kaser, L., Jud, W., Hansel, A., Docherty, K. S., Alexander, M. L., Robinson, N. H., Coe, H., Allan, J. D., Canagaratna, M. R., Paulot, F., and Jimenez, J. L.: Characterization of a real-time tracer for isoprene epoxydiols-derived secondary organic aerosol (IEPOX-SOA) from aerosol mass spectrometer measurements, Atmos. Chem. Phys., 15, 11807-11833, doi:10.5194/acp-15-11807-2015, 2015.

Jimenez, J. L., Canagaratna, M. R., Donahue, N. M., Prevot, A. S., Zhang, Q., Kroll, J. H., DeCarlo, P. F., Allan, J. D., Coe, H., Ng, N. L., Aiken, A. C., Docherty, K. S., Ulbrich, I. M., Grieshop, A. P., Robinson, A. L., Duplissy, J., Smith, J. D., Wilson, K. R., Lanz, V. A., Hueglin, C., Sun, Y. L., Tian, J., Laaksonen, A., Raatikainen, T., Rautiainen, J., Vaattovaara, P., Ehn, M., Kulmala, M., Tomlinson, J. M., Collins, D. R., Cubison, M. J., Dunlea, E. J., Huffman, J. A., Onasch, T. B., Alfarra, M. R., Williams, P. I., Bower, K., Kondo, Y., Schneider, J., Drewnick, F., Borrmann, S., Weimer, S., Demerjian, K., Salcedo, D., Cottrell, L., Griffin, R., Takami, A., Miyoshi, T., Hatakeyama, S., Shimono, A., Sun, J. Y., Zhang, Y. M., Dzepina, K., Kimmel, J. R., Sueper, D., Jayne, J. T., Herndon, S. C., Trimborn, A. M., Williams, L. R., Wood, E. C., Middlebrook, A. M., Kolb, C. E., Baltensperger, U., and Worsnop, D. R.: Evolution of organic aerosols in the atmosphere, Science, 326, 1525-1529, doi:10.1126/science.1180353, 2009.

Karvanen, J.: Study design in causal models, Scand. J. Stat., 42, 361-377, doi:10.1111/sjos.12110, 2015.

Kim, P. S., Jacob, D. J., Fisher, J. A., Travis, K., Yu, K., Zhu, L., Yantosca, R. M., Sulprizio, M. P., Jimenez, J. L., CampuzanoJost, P., Froyd, K. D., Liao, J., Hair, J. W., Fenn, M. A., Butler, C. F., Wagner, N. L., Gordon, T. D., Welti, A., Wennberg, P. O., Crounse, J. D., St. Clair, J. M., Teng, A. P., Millet, D. B., Schwarz, J. P., Markovic, M. Z., and Perring, A. E.: Sources, seasonality, and trends of southeast US aerosol: an integrated analysis of surface, aircraft, and satellite observations with the GEOS-Chem chemical transport model, Atmos. Chem. Phys., 15, 10411-10433, doi:10.5194/acp-15-10411-2015, 2015. 
Kline, R. B.: Principles and practice of structural equation modeling, Guilford publications, The Guilford Press, New York, USA, 2015.

Koop, T., Bookhold, J., Shiraiwa, M., and Pöschl, U.: Glass transition and phase state of organic compounds: dependency on molecular properties and implications for secondary organic aerosols in the atmosphere, Phys. Chem. Chem. Phys., 13, 19238-19255, doi:10.1039/c1cp22617g, 2011.

Kroll, J. H., Donahue, N. M., Jimenez, J. L., Kessler, S. H., Canagaratna, M. R., Wilson, K. R., Altieri, K. E., Mazzoleni, L. R., Wozniak, A. S., and Bluhm, H.: Carbon oxidation state as a metric for describing the chemistry of atmospheric organic aerosol, Nature Chem., 3, 133-139, doi:10.1038/NCHEM.948, 2011.

Kuwata, M. and Martin, S. T.: Particle size distributions following condensational growth in continuous flow aerosol reactors as derived from residence time distributions: Theoretical development and application to secondary organic aerosol, Aerosol Sci. Tech., 46, 937-949, doi:10.1080/02786826.2012.683204, 2012.

Lee, B. H., Mohr, C., Lopez-Hilfiker, F. D., Lutz, A., Hallquist, M., Lee, L., Romer, P., Cohen, R. C., Iyer, S., Kurten, T., Hu, W., Day, D. A., Campuzano-Jost, P., Jimenez, J. L., Xu, L., Ng, N. L., Guo, H., Weber, R. J., Wild, R. J., Brown, S. S., Koss, A., de Gouw, J., Olson, K., Goldstein, A. H., Seco, R., Kim, S., McAvey, K., Shepson, P. B., Starn, T., Baumann, K., Edgerton, E. S., Liu, J., Shilling, J. E., Miller, D. O., Brune, W., Schobesberger, S., D'Ambro, E. L., and Thornton, J. A.: Highly functionalized organic nitrates in the southeast United States: Contribution to secondary organic aerosol and reactive nitrogen budgets, P. Natl. Acad. Sci. USA, 113, 1516-1521, doi:10.1073/pnas.1508108113, 2016.

Li, Y. J., Liu, P., Gong, Z., Wang, Y., Bateman, A. P., Bergoend, C., Bertram, A. K., and Martin, S. T.: Chemical Reactivity and Liquid/Nonliquid States of Secondary Organic Material, Environ. Sci. Technol., 49, 13264-13274, doi:10.1021/acs.est.5b03392, 2015.

Lienhard, D. M., Huisman, A. J., Bones, D. L., Te, Y., Luo, B. P., Krieger, U. K., and Reid, J. P.: Retrieving the translational diffusion coefficient of water from experiments on single levitated aerosol droplets, Phys. Chem. Chem. Phys., 16, 16677-16683, doi:10.1039/c4cp01939c, 2014.

Massoli, P., Lambe, A., Ahern, A., Williams, L., Ehn, M., Mikkilä, J., Canagaratna, M., Brune, W., Onasch, T., and Jayne, J.: Relationship between aerosol oxidation level and hygroscopic properties of laboratory generated secondary organic aerosol (SOA) particles, Geophys. Res. Lett., 37, L24801, doi:10.1029/2011GL046687, 2010.

Meyer, N. K., Duplissy, J., Gysel, M., Metzger, A., Dommen, J., Weingartner, E., Alfarra, M. R., Prevot, A. S. H., Fletcher, C., Good, N., McFiggans, G., Jonsson, A. M., Hallquist, M., Baltensperger, U., and Ristovski, Z. D.: Analysis of the hygroscopic and volatile properties of ammonium sulphate seeded and unseeded SOA particles, Atmos. Chem. Phys., 9, 721-732, doi:10.5194/acp-9-721-2009, 2009.

Nenes, A., Pandis, S. N., and Pilinis, C.: ISORROPIA: A new thermodynamic equilibrium model for multiphase multicomponent inorganic aerosols, Aquat. Geochem., 4, 123-152, 1998.

Nguyen, T. K. V., Petters, M. D., Suda, S. R., Guo, H., Weber, R. J., and Carlton, A. G.: Trends in particle-phase liquid water during the Southern Oxidant and Aerosol Study, Atmos. Chem. Phys. 14, 10911-10930, doi:10.5194/acp-14-10911-2014, 2014.

Ortega, A. M., Hayes, P. L., Peng, Z., Palm, B. B., Hu, W., Day, D. A., Li, R., Cubison, M. J., Brune, W. H., Graus, M., Warneke, C., Gilman, J. B., Kuster, W. C., de Gouw, J., Gutiérrez-Montes, C., and Jimenez, J. L.: Real-time measurements of secondary organic aerosol formation and aging from ambient air in an oxidation flow reactor in the Los Angeles area, Atmos. Chem. Phys., 16, 7411-7433, doi:10.5194/acp-16-7411-2016, 2016.

Pajunoja, A., Malila, J., Hao, L., Joutsensaari, J., Lehtinen, K. E., and Virtanen, A.: Estimating the viscosity range of SOA particles based on their coalescence time, Aerosol Sci. Tech., 48, i-iv, doi:10.1080/02786826.2013.870325, 2014.

Pajunoja, A., Lambe, A. T., Hakala, J., Rastak, N., Cummings, M. J., Brogan, J. F., Hao, L., Paramonov, M., Hong, J., and Prisle, N. L.: Adsorptive uptake of water by semisolid secondary organic aerosols, Geophys. Res. Lett., 42, 3063-3068, doi:10.1002/2015GL063142, 2015.

Palm, B. B., Campuzano-Jost, P., Ortega, A. M., Day, D. A., Kaser, L., Jud, W., Karl, T., Hansel, A., Hunter, J. F., Cross, E. S., Kroll, J. H., Peng, Z., Brune, W. H., and Jimenez, J. L.: In situ secondary organic aerosol formation from ambient pine forest air using an oxidation flow reactor, Atmos. Chem. Phys., 16, 2943 2970, doi:10.5194/acp-16-2943-2016, 2016.

Pearl, J.: Causality, Cambridge University Press, Cambridge, UK, 2009.

Peng, Z., Day, D. A., Ortega, A. M., Palm, B. B., Hu, W., Stark, H., Li, R., Tsigaridis, K., Brune, W. H., and Jimenez, J. L.: Non-OH chemistry in oxidation flow reactors for the study of atmospheric chemistry systematically examined by modeling, Atmos. Chem Phys., 16, 4283-4305, doi:10.5194/acp-16-4283-2016, 2016.

Perraud, V., Bruns, E. A., Ezell, M. J., Johnson, S. N., Yu, Y., Alexander, M. L., Zelenyuk, A., Imre, D., Chang, W. L., and Dabdub, D.: Nonequilibrium atmospheric secondary organic aerosol formation and growth, P. Natl. Acad. Sci., 109, 28362841, doi:10.1073/pnas.1119909109, 2012.

Petters, M. D. and Kreidenweis, S. M.: A single parameter representation of hygroscopic growth and cloud condensation nucleus activity, Atmos. Chem. Phys., 7, 1961-1971, doi:10.5194/acp-71961-2007, 2007.

Price, H. C., Murray, B. J., Mattsson, J., O’Sullivan, D., Wilson, T. W., Baustian, K. J., and Benning, L. G.: Quantifying water diffusion in high-viscosity and glassy aqueous solutions using a Raman isotope tracer method, Atmos. Chem. Phys., 14, 3817 3830, doi:10.5194/acp-14-3817-2014, 2014.

Renbaum-Wolff, L., Grayson, J. W., Bateman, A. P., Kuwata, M., Sellier, M., Murray, B. J., Shilling, J. E., Martin, S. T., and Bertram, A. K.: Viscosity of alpha-pinene secondary organic material and implications for particle growth and reactivity, P. Natl. Acad. Sci. USA, 110, 8014-8019, doi:10.1073/pnas.1219548110, 2013.

Riipinen, I., Yli-Juuti, T., Pierce, J. R., Petäjä, T., Worsnop, D. R., Kulmala, M., and Donahue, N. M.: The contribution of organics to atmospheric nanoparticle growth, Nat. Geosci., 5, 453-458, doi:10.1038/ngeo1499, 2012.

Saleh, R., Shihadeh, A., and Khlystov, A.: On transport phenomena and equilibration time scales in thermodenuders, Atmos. Meas. Tech., 4, 571-581, doi:10.5194/amt-4-571-2011, 2011. 
Saukko, E., Lambe, A. T., Massoli, P., Koop, T., Wright, J. P., Croasdale, D. R., Pedernera, D. A., Onasch, T. B., Laaksonen, A., Davidovits, P., Worsnop, D. R., and Virtanen, A.: Humiditydependent phase state of SOA particles from biogenic and anthropogenic precursors, Atmos. Chem. Phys., 12, 7517-7529, doi:10.5194/acp-12-7517-2012, 2012.

Saukko, E., Zorn, S., Kuwata, M., Keskinen, J., and Virtanen A.: Phase State and Deliquescence Hysteresis of AmmoniumSulfate-Seeded Secondary Organic Aerosol, Aerosol Sci. Tech., 49, 531-537, doi:10.1080/02786826.2015.1050085, 2015.

Scott, C. E., Spracklen, D. V., Pierce, J. R., Riipinen, I., D'Andrea, S. D., Rap, A., Carslaw, K. S., Forster, P. M., Artaxo, P., Kulmala, M., Rizzo, L. V., Swietlicki, E., Mann, G. W., and Pringle, K. J.: Impact of gas-to-particle partitioning approaches on the simulated radiative effects of biogenic secondary organic aerosol, Atmos. Chem. Phys., 15, 12989-13001, doi:10.5194/acp-1512989-2015, 2015.

Shiraiwa, M. and Seinfeld, J. H.: Equilibration timescale of atmospheric secondary organic aerosol partitioning, Geophys. Res. Lett., 39, L24801, doi:10.1029/2012GL054008, 2012.

Shiraiwa, M., Ammann, M., Koop, T., and Pöschl, U.: Gas uptake and chemical aging of semisolid organic aerosol particles, P. Natl. Acad. Sci., 108, 11003-11008, doi:10.1073/pnas.1103045108, 2011.

Shiraiwa, M., Zuend, A., Bertram, A. K., and Seinfeld, J. H.: Gasparticle partitioning of atmospheric aerosols: interplay of physical state, non-ideal mixing and morphology, Phys. Chem. Chem. Phys., 15, 11441-11453, doi:10.1039/C3CP51595H, 2013.

Shrivastava, M., Zelenyuk, A., Imre, D., Easter, R., Beranek, J., Zaveri, R. A., and Fast, J.: Implications of low volatility SOA and gas-phase fragmentation reactions on SOA loadings and their spatial and temporal evolution in the atmosphere, J. Geophys. Res.-Atmos., 118, 3328-3342, doi:10.1002/jgrd.50160, 2013.

Smith, M. L., Bertram, A. K., and Martin, S. T.: Deliquescence, efflorescence, and phase miscibility of mixed particles of ammonium sulfate and isoprene-derived secondary organic material, Atmos. Chem. Phys., 12, 9613-9628, doi:10.5194/acp-12-96132012, 2012.

Song, M., Liu, P. F., Hanna, S. J., Li, Y. J., Martin, S. T., and Bertram, A. K.: Relative humidity-dependent viscosities of isoprene-derived secondary organic material and atmospheric implications for isoprene-dominant forests, Atmos. Chem. Phys., 15, 5145-5159, doi:10.5194/acp-15-5145-2015, 2015.

Stocker, T., Qin, D., Plattner, G., Tignor, M., Allen, S. K., Boschung, J., Nauels, A., Xia, Y., Bex, V., and Midgley, P. M.: Climate change 2013: The physical science basis, Cambridge University Press Cambridge, UK, and New York, USA, 2014.

Tang, I. and Munkelwitz, H.: Water activities, densities, and refractive indices of aqueous sulfates and sodium nitrate droplets of atmospheric importance, J. Geophys. Res.-Atmos., 99, 1880118808, doi:10.1029/94JD01345, 1994.

Tritscher, T., Dommen, J., DeCarlo, P. F., Gysel, M., Barmet, P. B., Praplan, A. P., Weingartner, E., Prévôt, A. S. H., Riipinen, I., Donahue, N. M., and Baltensperger, U.: Volatility and hygroscopicity of aging secondary organic aerosol in a smog chamber, Atmos. Chem. Phys., 11, 11477-11496, doi:10.5194/acp-1111477-2011, 2011.
Vaden, T. D., Imre, D., Beranek, J., Shrivastava, M., and Zelenyuk, A.: Evaporation kinetics and phase of laboratory and ambient secondary organic aerosol, P. Natl. Acad. Sci. USA, 108, 21902195, doi:10.1073/pnas.1013391108, 2011.

Virtanen, A., Joutsensaari, J., Koop, T., Kannosto, J., Yli-Pirilä, P., Leskinen, J., Mäkelä, J. M., Holopainen, J. K., Pöschl, U., and Kulmala, M.: An amorphous solid state of biogenic secondary organic aerosol particles, Nature, 467, 824-827, doi:10.1038/nature09455, 2010.

Virtanen, A., Kannosto, J., Kuuluvainen, H., Arffman, A., Joutsensaari, J., Saukko, E., Hao, L., Yli-Pirilä, P., Tiitta, P., Holopainen, J. K., Keskinen, J., Worsnop, D. R., Smith, J. N., and Laaksonen, A.: Bounce behavior of freshly nucleated biogenic secondary organic aerosol particles, Atmos. Chem. Phys., 11, 8759-8766, doi:10.5194/acp-11-8759-2011, 2011.

Wang, B., Lambe, A. T., Massoli, P., Onasch, T. B., Davidovits, P., Worsnop, D. R., and Knopf, D. A.: The deposition ice nucleation and immersion freezing potential of amorphous secondary organic aerosol: Pathways for ice and mixedphase cloud formation, J. Geophys. Res.-Atmos., 117, D16209, doi:10.1029/2012JD018063, 2012.

Wang, B., O’Brien, R. E., Kelly, S. T., Shilling, J. E., Moffet, R. C., Gilles, M. K., and Laskin, A.: Reactivity of liquid and semisolid secondary organic carbon with chloride and nitrate in atmospheric aerosols, J. Phys. Chem. A, 119, 4498-4508, doi:10.1021/jp510336q, 2014.

Xu, L., Guo, H., Boyd, C. M., Klein, M., Bougiatioti, A., Cerully, K. M., Hite, J. R., Isaacman-VanWertz, G., Kreisberg, N. M., Knote, C., Olson, K., Koss, A., Goldstein, A. H., Hering, S. V., de Gouw, J., Baumann, K., Lee, S. H., Nenes, A., Weber, R. J., and Ng, N. L.: Effects of anthropogenic emissions on aerosol formation from isoprene and monoterpenes in the southeastern United States, P. Natl. Acad. Sci. USA, 112, 37-42, doi:10.1073/pnas.1512279112, 2015.

Zaveri, R. A., Easter, R. C., Shilling, J. E., and Seinfeld, J. H.: Modeling kinetic partitioning of secondary organic aerosol and size distribution dynamics: representing effects of volatility, phase state, and particle-phase reaction, Atmos. Chem. Phys., 14, 5153-5181, doi:10.5194/acp-14-5153-2014, 2014.

Zhang, Y., Sanchez, M. S., Douet, C., Wang, Y., Bateman, A. P., Gong, Z., Kuwata, M., Renbaum-Wolff, L., Sato, B. B., Liu, P. F., Bertram, A. K., Geiger, F. M., and Martin, S. T.: Changing shapes and implied viscosities of suspended submicron particles, Atmos. Chem. Phys., 15, 7819-7829, doi:10.5194/acp-15-78192015, 2015.

Zobrist, B., Soonsin, V., Luo, B. P., Krieger, U. K., Marcolli, C., Peter, T., and Koop, T.: Ultra-slow water diffusion in aqueous sucrose glasses, Phys. Chem. Chem. Phys., 13, 3514-3526, doi:10.1039/c0cp01273d, 2011. 